\title{
A Research on Buying Behaviour on Organic Foods with Special Reference to Erode District
}

\author{
A. Jafersadhiq, S. Nagarajan
}

\begin{abstract}
Organic' is the term which is used frequently nowa-days by the consumers all over the world. The problem of the study is people are already living in the place which is polluted in all means - air, water and land and in-addition to that the food which they take in is also polluted with fertilizer, pesticides, etc., This practice is been followed knowingly or unknowingly for so many decades. Organic food products are becoming popular in many cities in India. The study has identified in Erode as one of the area where people are started to buy organic food product. The organic market in India is identified as one of the fast growing sector. The objective of the study is to examine the awareness on purchase of organic food products, to analyze the motivational factors towards purchase of organic food, to analyze the purchase pattern towards organic food and to know the satisfaction level of consumers and problems faced by them. There are five research tools has been used for the study, those are Simple percentage analysis, chi-square, ANOVA, Friedman Rank test, Descriptive Statistics. The marketers of organic food products need to be innovative and dynamic in order to complete with the changing purchase behaviour in the organic food products market among urban residents. The study brought out the fact that the people are well aware of images and availability, but not loyal entirely to organic food products .So the marketers must create promotions which are both realistic and moral.
\end{abstract}

Key words: Organic Food, Buying behaviour, Awareness level, satisfaction level etc.

\section{INTRODUCTION}

In today's world with lots of technology growth, people are living with goals and objective to be achieved and which is been accompanied by stress and illness. The life expectancy of a human has increased because of innovation in medical science but the healthy life has reduced. So the people have started to distinguish the food as healthy food and unhealthy food. This perception made them to search for a healthy food, which means, food without any chemical substance. The search of healthy food ends at organic food products.

In recent days people change their life from traditional to modern. The culture also changing day by day. Its one of the factor affects individual to buy the products. But now a days people came to know about the causes of instant foods. So people they aware about organic foods now a days.

Recent days people like to buy organic food products. Organic food producing industries getting fast growth rate now a days.

These products are produced without synthetic chemical products..

Revised Manuscript Received on September 14, 2019.

Dr. A. Jafersadhiq, Author, Assistant Professor, Management Studies, Erode Sengunthar Engineering College, Erode, Tamilnadu, India. (Email: jaferm505@gmail.com)

Mr. S. Nagarajan, Co-author, Assistant Professor, School of Management Studies, Bannari Amman Institute of Technology, Erode, Tamilnadu, India.(Email: nagarajans@bitsathy.ac.in).
Organic food production is an very significant area in india now a days. Now the people think about the importance of organic food products because they realize the value of natural foods. It includes healthy products and added natural resources. The quality of natural food gives the healthy and satisfaction to the consumers. So people in their busy schedule they are searching the natural foods to consume. For example In summer holidays people not prefer the soft drinks, they prefer the soft drinks like tender coconut due to understanding the value of natural food only. The cultural factors and social factors affect the people to buy the organic foods.

\section{Organic Vegetables and Fruits:}

The above products are available in the market with more number of suppliers. So people they prefer to buy the organic foods but not hybrid products.

Organic Meat:

It is produced naturally and not given the antibiotics or growth hormones. It is good for meat lovers for free from chemicals.

Organic Dairy Products:

Milk products are healthier for all age group of people. Even doctors prescribed to use milk for protein and vitamins to people.

\section{Consumer Behaviour:}

Consumer behaviour is the act of an separate customer is involved in securing and using goods and services. It also includes managerial process, which leads to the act of buying. The study deals with the behaviour of the human, which is subject to change from time to time. Marketers are in a position to study consumer behaviour from various approaches like the factors influencing them to buying, elements involved in it etc. It includes fundamentals like mind, sociology, social anthropology and economics. The factors influencing the customers to buy any product could be family, friends, reasonable price, easy availability of product, quality of the product etc.

\section{Meaning :}

The Consumer Behaviour is to study the consumers behavior in purchasing of a product. There are many factors influence the consumers to buy the particular product. There are,

\section{- Cultural factors}

Belief, languages are the major factors to influence the people to change themselves. 
Subculture - Each culture contains of lesser separation named subgroups that offers more detailed identification and social structure for its persons. Subculture contains peoples, religions, social groups and geographical regions. Subcultures are considered as an vital market sections and marketers often plan products and promotion plans which could provide to their needs.

- Social factors:

Family plays a vital role while purchasing the products. In family children's and elders plays a major role in purchasing decisions. Children's influence the elders to buy the product like elders influence the children's to buy the products.

- Personal factors:

Individuals age, economic factors, behavior going to decide the purchasing.

\section{Importance of Consumer Behaviour:}

1. To make better tactical marketing decisions. The marketer has whole information about the consumer's favorites, he can predict the customers' perception to his product or services.

2. The Government also want to study the consumer behaviour to provide them with the essential goods and services.

\section{STATEMENT OF THE PROBLEM}

The man made fertilizers, pesticides, insecticides etc. are used in farming which helped the crops to grow faster and insect-free produce, but it affected the humans very badly. The people are already living in the place which is polluted in all means - air, water and land and in-addition to that the food which they take in is also polluted with fertilizer, pesticides, etc., This practice is been followed knowingly or unknowingly for so many decades. Organic produce which is produced with-out any chemical manure is becoming popular among the public.

Customers, buying organic food products are increasing at a good speed. Many inorganic lands are becoming organic land and this shows that farmers has identified that people are turning towards organic food products. Marketers' job is to identify the strategy for sustainability in the market, this sustainability is based on the customer attitude towards the marketed products. The customer attitude includes many factors like preference, buying motive, satisfaction level on that particular products, etc. As the organic food products are in growing stage, this study started its research in measuring the awareness level, availability of organic food products then the customer preference, attitude towards price, their satisfaction level and also the re-purchase intention towards organic food products.

\section{SCOPE OF THE STUDY}

These products are becoming popular in many cities in India. The study has identified in Erode as one of the area where people are started to purchase the product. It is one of the growing sector. Few surveys had been taken place to know the position of organic products in Indian food industry and where do the India stand in world market. To sustain in the market the customer preference, buying motives their satisfaction level towards the products should be identified. This study will help to analyse the various factors like consumer preference, buying motives and their satisfaction level of consumers.

\section{OBJECTIVES}

$>\quad$ Study the awareness on purchase of products.

$>\quad$ Analyze the motivational aspects towards purchase of organic food

$>\quad$ Analyze purchase pattern towards organic food.

$>\quad$ Analyse the satisfaction level of consumers and problems faced by them.

\section{ANALYSIS \& RESULTS}

\section{DEMOGRAPHIC PROFILE OF RESPONDENT}

It depicts the classification of respondents by means of simple percentage which used to convert qualitative information to quantitative data.

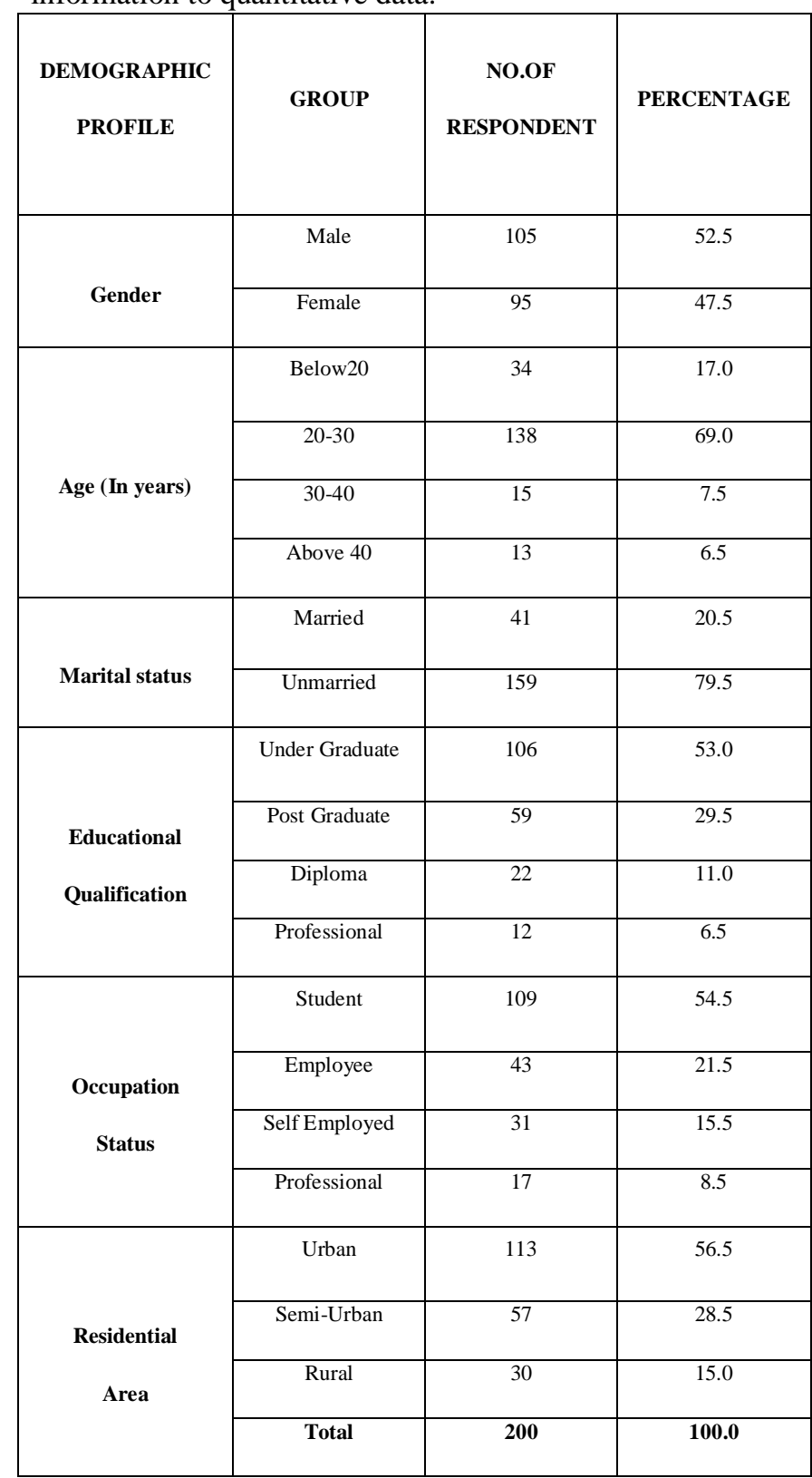




\section{Gender:}

It is inferred that the majority of them are ( 5.25 per cent) male respondents.

\section{Age:}

There are 17.0 per cent are below 20 years. 69.0 per cent are between 20-30 years, 7.5 per cent are between $7.0 \%$ and 6.5 per cent are above 40 .

\section{MARITAL STATUS}

There are $20.5 \%$ respondents are married $\& 79.5 \%$ are unmarried.

\section{EDUCATIONAL QUALIFICATION}

The study shows 53.0 per cent respondents are under graduate, 29.5 per cent are post graduate, 11.0 per cent are diploma and 6.5 are professionals.

\section{OCCUPATIONAL STATUS}

The status of the respondents are 54.5 per cent are students, 21.5 per cent are employees, 15.5 per cent are selfemployed and 8.5 per cent are professionals.

\section{RESIDENTIAL STATUS}

The urban area respondents are 56.5 per cent, 28.5 per cent are from semi-uban, 15.0 are from rural.

Anova For Motivational Factors Makes To Prefer

Organic Food Products Among The Variable Of

Personal Profile

\begin{tabular}{|c|c|c|c|c|c|c|c|}
\hline Variable & Source & $\begin{array}{l}\text { Sum } \\
\text { of } \\
\text { Squar } \\
\text { e }\end{array}$ & $\begin{array}{l}\text { Degree } \\
\text { of } \\
\text { Freedo } \\
\mathbf{m}\end{array}$ & $\begin{array}{l}\text { Mean } \\
\text { Squar } \\
\text { e }\end{array}$ & $\begin{array}{l}\text { F } \\
\text { rati }\end{array}$ & sig. & $\begin{array}{l}\text { Inferen } \\
\text { ce }\end{array}$ \\
\hline \multirow[t]{2}{*}{ Age } & $\begin{array}{l}\text { Betwee } \\
\mathrm{n} \\
\text { Groups }\end{array}$ & 1.392 & 3 & .464 & \multirow[t]{2}{*}{$\begin{array}{l}2.78 \\
0\end{array}$} & \multirow[t]{2}{*}{$\begin{array}{l}.04 \\
2\end{array}$} & \multirow[t]{2}{*}{ NS } \\
\hline & $\begin{array}{l}\text { Within } \\
\text { Groups }\end{array}$ & $\begin{array}{l}32.70 \\
8\end{array}$ & 196 & .167 & & & \\
\hline \multirow{2}{*}{$\begin{array}{l}\text { Educationa } \\
\text { l } \\
\text { Qualificatio } \\
\text { n }\end{array}$} & $\begin{array}{l}\text { Betwee } \\
\mathrm{n} \\
\text { Groups }\end{array}$ & 1.166 & 3 & .389 & \multirow[t]{2}{*}{$\begin{array}{l}2.31 \\
4\end{array}$} & \multirow[t]{2}{*}{$\begin{array}{l}.07 \\
7\end{array}$} & \multirow{2}{*}{ NS } \\
\hline & $\begin{array}{l}\text { Within } \\
\text { Groups }\end{array}$ & $\begin{array}{l}32.93 \\
4\end{array}$ & 196 & .168 & & & \\
\hline \multirow{2}{*}{$\begin{array}{l}\text { Occupation } \\
\text { al Status }\end{array}$} & $\begin{array}{l}\text { Betwee } \\
\mathrm{n} \\
\text { Groups }\end{array}$ & .526 & 3 & .175 & \multirow{2}{*}{$\begin{array}{l}1.02 \\
4\end{array}$} & \multirow{2}{*}{$\begin{array}{l}.38 \\
3\end{array}$} & \multirow{2}{*}{ NS } \\
\hline & $\begin{array}{l}\text { Within } \\
\text { Groups }\end{array}$ & $\begin{array}{l}33.57 \\
3\end{array}$ & 196 & .171 & & & \\
\hline \multirow{2}{*}{$\begin{array}{l}\text { Residential } \\
\text { Area }\end{array}$} & $\begin{array}{l}\text { Betwee } \\
\mathrm{n} \\
\text { Groups }\end{array}$ & 1.387 & 2 & .694 & \multirow[t]{2}{*}{$\begin{array}{l}4.17 \\
7\end{array}$} & \multirow[t]{2}{*}{$\begin{array}{l}.01 \\
7\end{array}$} & \multirow{2}{*}{ NS } \\
\hline & $\begin{array}{l}\text { Within } \\
\text { Groups }\end{array}$ & $\begin{array}{l}32.71 \\
3\end{array}$ & 197 & .166 & & & \\
\hline
\end{tabular}

\section{Source: Computed Data}

Age

The ANOVA table describes 0.042 is larger than 5\% level of significance. Since it is inferred that the awareness level of dimensions of products not differ. Hence, the null hypothesis is accepted.

\section{EDUCATIONAL QUALIFICATION}

The ANOVA table describes that 0.077 is more than the $5 \%$ level of significance. Since it is inferred that the awareness level among educational qualification of respondents. Hence, the null hypothesis is accepted.

\section{OCCUPATIONAL STATUS}

The ANOVA table indicates 0.383 is more than the $5 \%$ level of significance. The null hypothesis is accepted.

\section{RESIDENTIAL AREA}

The significance level is 0.017 is more than $5 \%$. So the null hypothesis is accepted.

Anova For Often Buying Behaviour To Prefer

Organic Food Products Between The Variables Of Personal Profile

\begin{tabular}{|c|c|c|c|c|c|c|c|}
\hline Variable & Source & $\begin{array}{l}\text { Sum } \\
\text { of } \\
\text { Squar } \\
\text { e }\end{array}$ & $\begin{array}{l}\text { Degree } \\
\text { of } \\
\text { Freedo } \\
\text { m }\end{array}$ & $\begin{array}{l}\text { Mean } \\
\text { Squar } \\
\text { e }\end{array}$ & $\begin{array}{l}\text { F } \\
\text { rati } \\
\text { o }\end{array}$ & sig. & $\begin{array}{l}\text { Inferen } \\
\text { ce }\end{array}$ \\
\hline \multirow[t]{2}{*}{ Age } & $\begin{array}{l}\text { Betwee } \\
\mathrm{n} \\
\text { Groups }\end{array}$ & 3.803 & 3 & 1.268 & \multirow[t]{2}{*}{$\begin{array}{l}1.12 \\
4\end{array}$} & \multirow[t]{2}{*}{$\begin{array}{l}.34 \\
1\end{array}$} & \multirow[t]{2}{*}{ NS } \\
\hline & $\begin{array}{l}\text { Within } \\
\text { Groups }\end{array}$ & $\begin{array}{l}221.10 \\
5\end{array}$ & 196 & 1.128 & & & \\
\hline \multirow{2}{*}{$\begin{array}{l}\text { Educationa } \\
\text { l } \\
\text { Qualificati } \\
\text { on }\end{array}$} & $\begin{array}{l}\text { Betwee } \\
\mathrm{n} \\
\text { Groups }\end{array}$ & 3.767 & 3 & 1.256 & \multirow[t]{2}{*}{$\begin{array}{l}1.11 \\
3\end{array}$} & \multirow[t]{2}{*}{$\begin{array}{l}.34 \\
5\end{array}$} & \multirow{2}{*}{ NS } \\
\hline & $\begin{array}{l}\text { Within } \\
\text { Groups }\end{array}$ & $\begin{array}{l}221.14 \\
1\end{array}$ & 196 & 1.128 & & & \\
\hline \multirow{2}{*}{$\begin{array}{l}\text { Occupation } \\
\text { al Status }\end{array}$} & $\begin{array}{l}\text { Betwee } \\
\mathrm{n} \\
\text { Groups }\end{array}$ & 6.431 & 3 & 2.144 & \multirow[t]{2}{*}{$\begin{array}{l}1.92 \\
3\end{array}$} & \multirow[t]{2}{*}{$\begin{array}{l}.12 \\
7\end{array}$} & \multirow{2}{*}{ NS } \\
\hline & $\begin{array}{l}\text { Within } \\
\text { Groups }\end{array}$ & $\begin{array}{l}218.47 \\
7\end{array}$ & 196 & 1.115 & & & \\
\hline \multirow[t]{2}{*}{ Residential } & $\begin{array}{l}\text { Betwee } \\
\text { n } \\
\text { Groups }\end{array}$ & 6.248 & 2 & 3.124 & \multirow[t]{2}{*}{$\begin{array}{l}2.81 \\
4\end{array}$} & \multirow[t]{2}{*}{$\begin{array}{l}.06 \\
2\end{array}$} & \multirow{2}{*}{ NS } \\
\hline & $\begin{array}{l}\text { Within } \\
\text { Groups }\end{array}$ & $\begin{array}{l}218.66 \\
0\end{array}$ & 197 & 1.110 & & & \\
\hline
\end{tabular}

Source: Computed Data

Age

The ANOVA table tells the significant value is 0.341.Since it is inferred that the awareness level of 
dimension is not differ. Hence, the null hypothesis is accepted.

\section{EDUCATIONAL QUALIFICATION}

The ANOVA table denotes the significant level is 0.345 . Since it is inferred that the awareness level not differentiated. Hence, the null hypothesis is accepted.

\section{OCCUPATIONAL STATUS}

The ANOVA table denotes the value is 0.127 is more than $5 \%$. Hence, the null hypothesis is accepted.

\section{RESIDENTIAL STATUS}

The ANOVA table denotes 0.62 is more than the 5\% level of significance. Hence, the null hypothesis is accepted.

\section{ANOVA FOR SATISFACTION LEVEL TO PREFER ORGANIC FOOD PRODUCTS AMONG THE VARIABLE OF PERSONAL PROFILE}

\begin{tabular}{|c|c|c|c|c|c|c|c|}
\hline Variable & Source & $\begin{array}{l}\text { Sum of } \\
\text { Square }\end{array}$ & $\begin{array}{l}\text { Degree } \\
\text { of } \\
\text { Freedom }\end{array}$ & $\begin{array}{l}\text { Mean } \\
\text { Square }\end{array}$ & $\begin{array}{l}\text { F } \\
\text { ratio }\end{array}$ & sig. & Inference \\
\hline \multirow[t]{2}{*}{ Age } & $\begin{array}{l}\text { Between } \\
\text { Groups }\end{array}$ & .780 & 3 & .260 & \multirow[t]{2}{*}{.621} & \multirow[t]{2}{*}{.602} & \multirow[t]{2}{*}{ NS } \\
\hline & Within Groups & 82.027 & 196 & .419 & & & \\
\hline \multirow{2}{*}{$\begin{array}{l}\text { Educational } \\
\text { Qualification }\end{array}$} & $\begin{array}{l}\text { Between } \\
\text { Groups }\end{array}$ & 2.865 & 3 & .955 & \multirow[t]{2}{*}{2.341} & \multirow[t]{2}{*}{.075} & \multirow{2}{*}{ NS } \\
\hline & Within Groups & 79.942 & 196 & .408 & & & \\
\hline \multirow{2}{*}{$\begin{array}{l}\text { Occupational } \\
\text { Status }\end{array}$} & $\begin{array}{l}\text { Between } \\
\text { Groups }\end{array}$ & 3.839 & 3 & 1.280 & \multirow[t]{2}{*}{3.177} & \multirow[t]{2}{*}{.025} & \multirow{2}{*}{ NS } \\
\hline & Within Groups & 78.968 & 196 & .403 & & & \\
\hline \multirow{2}{*}{$\begin{array}{l}\text { Residential } \\
\text { Area }\end{array}$} & $\begin{array}{l}\text { Between } \\
\text { Groups }\end{array}$ & .137 & 2 & .068 & \multirow[t]{2}{*}{.163} & \multirow[t]{2}{*}{.850} & \multirow{2}{*}{ NS } \\
\hline & Within Groups & 82.670 & 197 & .420 & & & \\
\hline
\end{tabular}

Source: Computed Data

\section{INTERPRETATION}

The ANOVA table value of age is 0.62 . The educational qualification value is 0.075 . Occupational status value is 0.025. Residential Area table value is 0.021. The above values are more than the $5 \%$ level of significance so the null hypothesis is accepted.

\begin{tabular}{|c|c|c|c|}
\hline S. NO & SOURCES & RESPONSES N & PERCENT \\
\hline 1 & $\mathrm{Tv}$ & 115 & 54.8per cent \\
\hline 2 & Newspaper & 12 & 5.7per cent \\
\hline 3 & Friends \& relative & 66 & 31.4per cent \\
\hline 4 & Super market staff & 7 & 3.3per cent \\
\hline 5 & Intemet ads & 10 & 4.8per cent \\
\hline & Total & 210 & 100.0per cent \\
\hline
\end{tabular}

Source: Prime Data

\section{INTERPRETATION}

There are 54.8per cent of the respondents influenced by tv, 31.4per cent of the respondents are influenced by friends $\&$ relatives 5.7per cent of the respondents are influenced by newspaper, while 4.8per cent of the respondents are influenced by internet ads. 3.3per cent of the respondents are influenced by super market staffs. Majority (54.8per cent) of the respondents are influenced by tv.

Difficulties Faced By The Consumer While Buying Organic Food Products

\begin{tabular}{|c|c|c|c|}
\hline S.NO & DIFFICULTIES & $\begin{array}{l}\text { MEAN } \\
\text { RANK }\end{array}$ & RANK \\
\hline 1 & Inadequate availability of products & 3.12 & 1 \\
\hline 2 & Less variety & 3.93 & 3 \\
\hline 3 & Organic products are expensive & 4.36 & 4 \\
\hline 4 & $\begin{array}{l}\text { No frequent tv ads and other advertisements regarding } \\
\text { organic food products }\end{array}$ & 3.82 & 2 \\
\hline 5 & Duplication of products & 4.61 & 5 \\
\hline 6 & Need for more maintenance & 5.37 & 7 \\
\hline 7 & Less knowledge about the product & 5.00 & 6 \\
\hline 8 & Need for more maintenance & 5.78 & 8 \\
\hline
\end{tabular}

\section{INTERPRETATION}

The "Inadequate availability of products" is given the highest rank (mean value 3.12), followed by the 'No frequent tv ads and other advertisements regarding organic food products". (mean value 3.82 ) are preferred to get "Less variety "(mean value 3.93) is the next important reason for preferring apps for 'Organic products are expensive (mean value 4.36) are preferring apps for the reason of 'Duplication of products.( mean value 4.61) is preferring apps for "Less knowledge about the product" (mean value $5.00)$. 'It is more attractive 'scored mean value of 5.37 follows the next rank of "Need for more maintenance". The 'Need for more maintenance", however, has been considered .

\section{REVIEW OF LITERATURE}

NAYANA SHARMA AND Dr. RITU SINGHVI (2019) in their study ('Consumer perception and behaviour towards organic food') The main objective of the study is to provide an current practices of market exposure towards consumers and organic foods.

They used data collections through surveys, direct interviews, books journals and magazines for their study. They have collected data's from 300 candidates from various resources. Through the study finally they concluded that purchasing behaviours can be influenced by consumers psychological factors.

Dr.V.PADMAJA AND NIKHIL PRASHAR (2018) in their study ('On consumer behaviour towards organic food products')

The objective is factors influences on buying behaviour, the income level of consumers and digital payment. The data was collected from 100

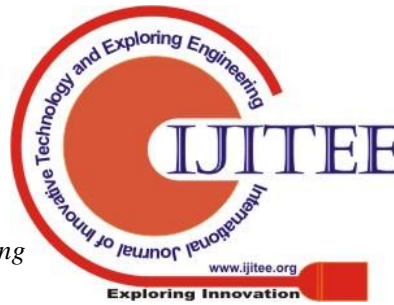


respondents, The study reveals that income in an individual does not influence on purchasing of products

VISHAL KUMAR LAHERI AND PURUSHOTTAM KUMAR ARYA (2018) in their study, emphasizes on the decision of consumers towards their consuming habits. The objective is to study the level of awareness, to identify the facilitators and barriers of purchasing organic food product. Survey was conducted among 45 respondents across different organic food products stores in Delhi. The study reveals that there is a need for organizing many awareness programs by the government $\&$ at the same time safe for the environment.

Dr.R.PARAMESHWARAN AND S.RAMAKRIHNA (2018) in their study analysis the impact of customers satisfaction on economic success on the organic food retail trade.

The main objectives are evaluation of satisfaction level of cunsumers and profit motive of sellers in shop. Analyse these two things wil tells the real factor of the study. There are 100 respondents has been taken for the study. The research tool is regression analysis. The important factor is customer satisfaction plays the vital role in market.

B.KRISHNAKUMARE AND S.NIRANJAN (2017), The main theme of the study is to identifies the which factor influence the consumers to buy the products and to know about consumers level of awareness and knowledge towards the purchasing of products. Totally 240 respondents has been taken for study. Finally the concluded that, the consumers psychological factors plays an individual to buy the products.

\section{FINDINGS}

Data collected from 200 respondents using questionnaire have been analysed and the consolidated results are shown below.

The age group of 20-30 respondents are 69.0\%. 79.5 percent is constituted of Unmarried respondents. The male respondents are $52.5 \%$, the under graduate holders are $53.0 \%$, the respondents from urban are is $56.5 \%$. No significance difference between age group, educational group, qualification, occupation, marital status, motivational factors and level of awareness.

\section{SUGGESTIONS}

On the basis of information obtained from the respondents, some suggestions are made.

The variety of organic foods are low.

$>\quad$ It has been found out that the variety aspects of organic food products is low. The variety of items should be increased for better satisfaction level.

The price of organic food product is high, though its reasonable the consumers are not being able to buy the product so reduction of price or offers will be helpful for the consumers.

The marketers to take further possible steps to induce the attraction level of consumers so that there will be more awareness.

To provide frequent advertisements in tv and internet can be telecasted. $>\quad$ More number of shops can be opened in such a way it will be useful for the consumers to buy them irrespective of the prices offered.

\section{CONCLUSION}

Consumers are important in market segment. The organic food producers need to create awareness about product features, benefits and advantages. They needs to utilise the market very effectively and to attract new customers. Now a days people prefer the traditional food items. People came to realise the benefits of organic foods. Modern food producers use various technologies and promotional activities like advertisements, sales promotions etc to attract consumers. So if marketers creates awareness and various advertisements means they can easily reach the consumers and the demand will be created more for organic foods in future.

\section{BIBLIOGRAPHY}

1. Alan d dangour et al (2009) Nutritional quality of organic foods : a systematic review The American Journal of Clinical Nutrition, Volume 90, Issue 3, 1 September 2009, Pages 680-685. 29 - july 2009.

2. B Krishnakumarae and S Niranjan (2017) Consumer's buying behaviour towards organic food products in Tamil Nadu ; Agricultural Economics Research Review ,Volume .30 (No.1) Jnuary-June 2017 pp133-138.

3. B lavanya and Dr. S.Saraswathy (2018) Conumers buying behaviour- a study with reference to organic food products Hyderbad city: International Journal of Engineering Technology Science and Research IJETSR ISSN 2394 - 3386 Volume 5, Issue 1 January 2018

4. Dr R Parameshwaran and S Ramakrishnan (2013) A study on consumer purchase behaviour towards organic products ,International journal of science and research (IJSR) ISSN (online) Index Copernicus vale (2013):6.14 / Impact factor (2013):4.438.

5. Dr v padmaja and Nikhil parashar (2018) A study on consumer behaviour towards organic food products : International journal of applied engineering research ISSN 0973-4562 Volume 13, number 1 (2018)pp. 10-12.

6. J Padamathy and R.Sarasawathy (2016) A study on the consumers buying behaviour towards organic food products in Thanjavur; intercontinental journal of marketing research review issn:2321-0346 - online issn:2347-1670 - print -impact factor :1.590 volume 4, issue 2, february 2016

7. Joris Aertsens et al (2019) Personal determinants of organic food consumption :a review :Faculty of bio science Engineering ; British food journal Vol.111.No 10, 2009 pp 1140-1167.

8. Konda kalyani (2017) Consumer preception towards organic food products in India :University College of Commerce and Business Management: December 2017 IJIRT | Volume 4 Issue 7 | ISSN: 2349-6002

9. Leila hamzaoui essoussi et al (2008) Decision making process of community organic food consumers; An exploratory study: Journal of consumer marketing 25/2 (2008) 95-101 Emerald publishing limited \{ISSN 07363761\}

10. Lina thatte et. al (2016) Analusing consumer behaviour towards organic food with special reference cities :Mumbai \& thane- Inyternational journal of application 
or innovation in engineering \& management ; Volume 5, Issue 8 , August 2016.

11. Manoranjan Dash et al (2014)Consumer preception towards orgainc food product International journal of engineering and management: Volume-4, Issue-3, June2014, ISSN No.: 2250-0758 Page Number: 110-113. 